\title{
Winter Variation in Nutrient and Fiber Con- tent and In vitro Digestibility of Gambel Oak [Quercus gambellii] and Big Sagebrush [Artemisia tridentata] from Diversified Sites in Colorado
}

\author{
ROLAND C. KUFELD, MARILYN STEVENS, AND DAVID C. BOWDEN
}

\section{Abstract}

Nutrient and fiber content and in vitro digestible dry matter (IVDDM) were measured in Gambel oak (Quercus gambellii) and big sagebrush (Artemisia tridentata) samples collected during January from nine geographic areas distributed widely throughout the western half of Colorado, and representing three vegetation types. Coefficients of variation among areas were less than $10 \%$ in both species in dry matter content, IVDDM and most cell and cell wall components. Variation appears to be small enough to permit application of a suitably selected, constant value, which would reflect winter nutrient content, fiber content or digestibility of these species, regardless of where collected in Colorado, in surveys where winter nutritional status of big game rangelands is being estimated for management purposes.

Management of big game range should include knowledge of the nutrient and fiber content and digestibility of existing forage plants during the critical winter period. Forage species which comprise winter big game diets must be high enough in digestibility and nutrient content to meet minimum animal requirements.

The current state of the art for evaluating nutritional status of winter rangelands involves chemical analysis of each forage species or of diet mixes to determine percent digestibility, fiber composition, and nutrient content. Each analysis is time consuming and expensive. If a number of winter ranges were being evaluated simultaneously, the time and cost of a detailed analysis of each plant species on each range would be exorbitant. Costs of evaluating a number of ranges could be reduced if variation among plants of the same species was small enough to permit application of suitably selected constants to be used to reflect winter nutrient content, fiber content, and digestibility of a species regardless of where collected. This would render it unnecessary to sample nutrient fiber or digestibility levels of individual species on each rangeland area of interest. In some cases it may be adequate merely to determine that the composite nutrient level for a piece of rangeland is above some minimum value rather than to measure actual composite nutrient levels.

Nutrient content levels in plants are influenced by numerous factors, including season of year, climate, weather, elevation, and light and soil constituents such as parent material, texture, depth, nutrient content, moisture, and temperature (Laycock and Price 1970). Cook and Harris (1950) concluded that "the nutrient content of forage is influenced by many interdependent factors and the result is the additive or mass effect of all factors operating simul-

Authors are, respectively, wildlife researcher and wildlife technician, Colorado Division of Wildlife, 317 West Prospect Street, Fort Collins, Colorado 80526, and associate professor of statistics, Colorado State University, Fort Collins, Colorado, 80523.

This study was financed in part by Federal Aid in Fish and Wildlife Restoration, Colorado Project W-126-R.

The authors gratefully acknowledge Dan Milchunas and Dan Baker for their assistance in conducting in vitro digestibility trials.

Manuscript received September $21,1979$. taneously." Therefore, use of a constant value for each species will provide an adequate approximation of the overall nutrient content, fiber content, or digestibility only if variation due to all factors is reasonably small. The purpose of this study was to determine extent of variation in nutrient content and digestibility of individual range forage species growing under widely diversified conditions and in different geographic locations. Two species, Gambel oak (Quercus gambellii) and big sagebrush (Artemisia tridentata), were selected for study. Due to difficulty in identifying sagebrush plants according to subspecies in the field most big game winter range surveys conducted to collect management data would measure forage production only to the species level. Therefore, big sagebrush collections in this study included all subspecies of $A$. tridentata in an effort to determine the degree of variation nutrient, fiber, and digestibility within the species as it occurs within Colorado.

\section{Methods}

The sampling system used in the study was designed to sample the range of diversity in environmental site factors existing with Gambel oak and big sagebrush habitat in Colorado. The design maximized distances between plant collection locations in order to encounter as much variation in nutrient and fiber content and digestibility as might likely exist within each plant species.

During January, 1976, samples of Gambel oak and big sagebrush were collected from designated geographic areas distributed widely throughout the entire western half of Colorado. Each species was collected from nine geographic areas although both specics werc not collected from the samc arcas. The ninc areas for each species represented three major vegetation types. Vegetation types selected were those in which Gambel oak and big sagebrush occur most commonly in Colorado. Three areas in which Gambel oak were collected represented the pinyon-juniper (Pinus edulisJuniperus osteosperma) type; three represented the Gambel oak type, and three more represented the ponderosa pine (Pinus ponderosa) type. Big sagebrush samples were collected in the big sagebrush, pinyon-juniper and Gambel oak types with three geographic areas representing each type. Vegetation types were described by Costello (1954). All collections of oak or sage within a given geographic area were made in the one vegetation type represented by that area.

One 70 to $100 \mathrm{~g}$ (green weight) sample of oak and sage was collected at each of five sites within each geographic area. Each sample was a composite of clippings from many plants growing on a site. The five collection sites within each geographic area were distributed throughout the area and separated by distances of at

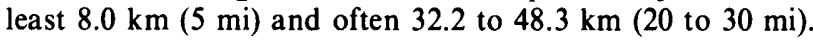

Plant collections consisted of current annual growth stems. Leaf remnants and acorns were excluded from oak samples. Leaves on sagebrush stems were included, but seed stalks were excluded. Samples of big sagebrush were sealed in plastic bags, refrigerated 
Table 1. Percent nutrient content in Gambel oak collected during January from 9 geographic areas distributed throughout Colorado1.

\begin{tabular}{|c|c|c|c|c|c|c|}
\hline \multirow[b]{3}{*}{ Nutrient } & \multicolumn{5}{|c|}{9 geographic area means } & \multirow{3}{*}{$\begin{array}{l}95 \% \text { Confidence } \\
\text { Interval for the } \\
\text { median of area } \\
\text { means }^{2}\end{array}$} \\
\hline & & \multirow{2}{*}{$\begin{array}{l}\text { Coefficient of } \\
\text { variation } \\
(\%)\end{array}$} & \multicolumn{3}{|c|}{ Range } & \\
\hline & Mean & & Minimum & Maximum & Median & \\
\hline Dry matter content & 64.1 & 1.9 & 62.0 & 65.8 & 64.2 & $62.8-65.8$ \\
\hline \multicolumn{7}{|c|}{ Cell Contents ${ }^{3}$} \\
\hline Crude protein & 5.1 & 6.1 & 4.6 & 5.4 & 5.2 & $4.6-5.3$ \\
\hline Soluble carbohydrate & 27.8 & 8.2 & 25.3 & 32.2 & 27.2 & $26.1-30.7$ \\
\hline Ether extract & 3.9 & 21.8 & 2.4 & 4.8 & 3.9 & $2.9-4.8$ \\
\hline Soluble ash & 4.0 & 6.2 & 3.7 & 4.4 & 4.1 & $3.7-4.2$ \\
\hline Total cell contents & 40.7 & 5.8 & 38.6 & 45.4 & 39.7 & $38.7-43.6$ \\
\hline \multicolumn{7}{|c|}{ Cell Walls ${ }^{3}$} \\
\hline Lignin & 24.0 & 9.2 & 21.0 & 28.2 & 24.0 & $22.1-26.0$ \\
\hline Hemicellulose & 10.1 & 19.7 & 7.0 & 12.7 & 10.3 & $7.7-11.8$ \\
\hline Cellulose & 24.1 & 10.8 & 18.4 & 27.1 & 24.4 & $22.0-26.7$ \\
\hline Holocellulose & 34.1 & 5.7 & 30.2 & 36.9 & 34.0 & $33.0-36.2$ \\
\hline Insoluble ash & 0.7 & 30.0 & 0.3 & 1.0 & 0.6 & $0.5-0.9$ \\
\hline Total cell walls & 59.3 & 3.4 & 54.6 & 61.4 & 60.3 & $56.4-61.4$ \\
\hline \multicolumn{7}{|c|}{ Digestibility $^{3}$} \\
\hline $\begin{array}{l}\text { In vitro digestible dry matter } \\
\text { (IVDDM) }\end{array}$ & 28.1 & 3.7 & 26.6 & 29.5 & 27.8 & $27.0-29.3$ \\
\hline
\end{tabular}

'Data are based on collections of five samples from widely separated locations within each of nine geographic areas throughout the western half of Colorado. ${ }^{2}$ Calculated using procedures described by Dixon and Massey (1969) p. 349.

${ }^{3}$ Values are based on $100 \%$ dry matter.

immediately upon collection, and frozen as soon thereafter as possible to minimize vaporization of essential oils, which might inflate digestion coefficients. Nagy et al. (1964) found that essential oils in big sagebrush inhibit rumen microorganism activity to some extent.

A portion of each sample was air and oven dried, ground, and analyzed to determine content of the following: dry matter; total cell contents including crude protein (Kjeldahl $\mathrm{N} \times 6.25$ ), ether extract, soluble ash; soluble carbohydrate (Assoc. Offl. Agr. Chem. 1965); total cell walls including acid insoluble ash, lignin, hemicellulose, cellulose, holocellulose (Fonnesbeck and Harris $1970 \mathrm{a}, 1970 \mathrm{~b}, 1971)$. The remaining portion of each sample was retained for determination of in vitro digestible dry matter (IVDDM) using Pearson's (1970) modification of the method described by Tilley and Terry (1963). Inoculum used was from a
Holstein cow fed a ration of native grass hay. Sagebrush samples used in IVDDM trials were freeze dried before grinding to prevent essential oil vaporization.

A corollary experiment was conducted to determine the magnitude of essential oil loss which occurs in big sagebrush during the freeze drying and grinding process. During February 1976, one composite big sagebrush sample of at least 200 grams was collected from each of ten geographic areas distributed widely throughout the western half of Colorado. These ten areas differed to some extent from the nine from which previously described collections were made. Procedures described previously were used for collecting except that the two halves of each sample were packaged separately, making ten paired samples. One sample of each pair was freeze dried and ground as prescribed for all other sagebrush samples used in in vitro digestibility trials. These were weighed

Table 2. Percent nutrient content in big sagebrush collected during January from 9 geographic areas distributed throughout Colorado. ${ }^{1}$

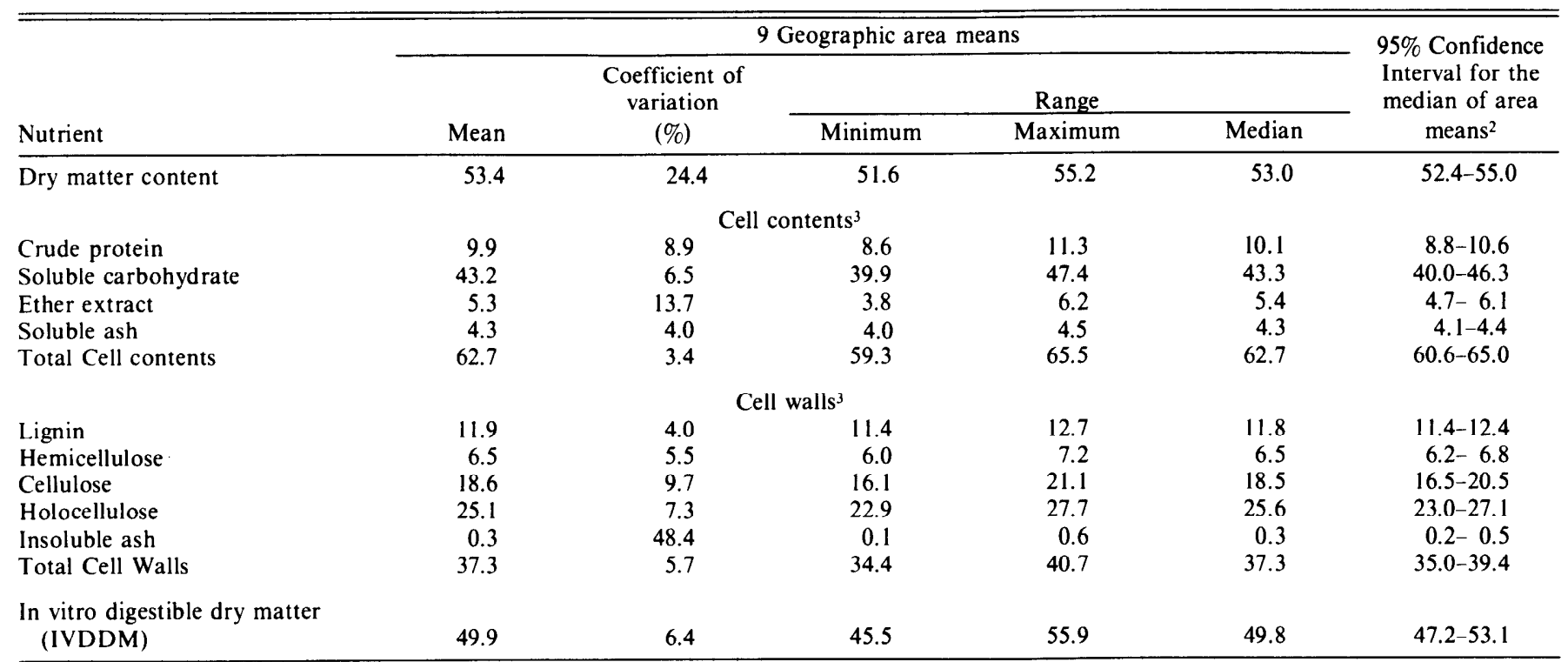

'Data are based on collections of five samples from widely separated locations within each of nine geographic areas throughout the western half of Colorado. 'Calculated using procedures described by Dixon and Massey (1969) p. 349.

${ }^{3}$ Values are based on $100 \%$ dry matter. 
after freeze drying to determine remaining moisture content. The green half of each sample was adjusted to dry weight on the basis of moisture content in the freeze dried samples. Both samples of each pair were then distilled using procedures described by Ward and Nagy (1966), and percent essential oil loss was compared.

\section{Results and Discussion}

Since collection site selections were not made at random, but with the objective of maximizing within area variability it is assumed that coefficients of variation among oak and sagebrush collections made during the study (Tables 1 and 2 ) are larger than would be obtained under random sampling. Hence reported $\mathrm{CV}$ values are conservative relative to the objectives of the study. Levels of significance obtained from analysis of variance procedures should also be conservative.

A further explanation at this point may also aid the reader in interpreting results presented. Knowledge of the average or at least the minimum nutrient content and digestibility level for plants on each winter range (viewed in this experiment as a geographic area) is of interest since a big game animal either lives or dies on its own range during the crucial winter period. A "mean"(nutrient content, fiber content or digestibility of samples from five sites within a range or geographic area) appears to be an appropriate statistic for describing plant nutrient, fiber or digestibility levels available to animals on an individual range (or geographic area). On the other hand a mean found by averaging the nine geographic area means would represent nutrient or digestibility levels available to individual animals only if variation was low and means for all ranges (or areas) were similar. A median becomes a more meaningful statistic than a mean for use as a constant value to represent nutrient, fiber, or digestibility levels available to animals on several ranges or geographic areas in cases where variation is judged too la rge to permit use of an over-all mean. A median value for means of individual ranges (or geographic areas) allows one to say that at least $50 \%$ of the individual ranges (or areas) had nutrient levels above the given median value. Assuming that collection sites within ranges or geographic areas were selected at random, the smallest area mean can be used to form a one-sided, nonparametric tolerance level (Dixon and Massey 1969, p. 348), which reflects the proportion of the ranges (or areas) with plant nutrient, fiber, or digestibility levels above the smallest mean area value at a given level of confidence. In the absence of random sampling it is expected that the proportion of ranges or geographic areas with mean plant nutrient, fiber, or digestibility levels greater than the smallest area mean exceeds the proportion determined by random sampling. Since it is desirable that nutrient, fiber and digestibility be underestimated rather than overestimated to avoid overstocking, one-sided, nonparametric tolerance levels can be used to minimize the decision-making error incurred in projecting nutrient, fiber and digestibility levels based on "average" values. A suitably selected constant for describing plant nutrient, fiber, or digestibility levels could, therefore, be (1) an over-all mean for collections from all ranges or geographic areas, or it could be (2) a median value of area means, or (3) a lower nonparametric tolerance limit for nutrient, fiber, and digestibility values available on individual ranges or geographic areas.

Analysis of variance revealed significant differences $(P \leq .05)$ among vegetation types, among geographic areas, and among areas within vegetation types for most nutrient and fiber components in both Gambel oak and big sagebrush. Even though differences occurred which are statistically significant, the degree of variation as reflected by coefficients of variation among the nine area mean values (Tables 1 and 2) is relatively small. For oak, the mean crude protein level of the nine geographic areas means was $5.1 \%$ and $\mathrm{CV}$ was $6.1 \%$. The median was $5.2 \%$. For big sagebrush the mean crude protein level was $9.9 \%$ and $\mathrm{CV}$ was $8.9 \%$. The median was $10.1 \%$. Data reflect relatively little mid-winter variation from one locality to another in content of most of the other nutrients and fiber components in both species. Coefficients of variation in dry matter content, cell content, and cell wall constitu- nts were less than $10 \%$ in both shrub species except for hemicellulose and cellulose in oak and ether extract and insoluble ash in oak and sage.

The coefficient of variation among area means for IVDDM was $3.7 \%$ for Gambel oak and $6.4 \%$ for big sagebrush (Tables 1 and 2). If yield of digestible forage during winter was being measured on several parcels of western Colorado rangelands, use of mean or median IVDDM values of 28.1 and $27.8 \%$ respectively for Gambel oak, and 49.9 ro $49.8 \%$, respectively, for big sagebrush should provide a relatively accurate estimate of IVDDM levels for those species.

Minimum values for the range of nine geographic area means shown in Tables 1 and 2 represent nonparametric lower limits for dry matter, nutrient and fiber components and digestibility for each species. The following is an example of the utility of these values: Using nine area sample means (based on 5 sa mples per a rea) which range from 26.6 to $29.5 \%$ IVDDM for oak (Table 1), one can bc $95 \%$ sure that at least $70 \%$ of the geographic area mean IVDDM values encountered in Gambel oak in Colorado, during January, would exceed the minimum value of $26.6 \%$. By using the minimum value one could be reasonably sure his estimate of IVDDM production is conservative.

Variation in nutrient and fiber content and IVDDM appears to be small enough to permit application of mean or median values for Gambel oak and big sagebrush with a reasonable degree of accuracy where winter nutritional status of rangelands is being estimated for management purposes. Nonparametric tolerance levels should be employed to insure that estimates of nutrient and fiber production and digestibility based on such data are conservative.

Ten big sagebrush samples distilled in fresh conditions contained $1.3036 \pm .0924 \%$ essential oil (mean \pm SE) compared with $1.1123 \pm .1232 \%$ for ten samples distilled after being freeze dried and ground. These data indicate a $14.7 \%$ loss of essential oils due to the freeze drying and grinding process. A paired $t$-test, however, indicated the loss was not significant $(P>.05)$. This suggests that the process of freeze drying and grinding of big sage samples preparatory to analysis of IVDDM resulted in only a minor loss of essential oils through vaporization, and did not cause inflated digestion coefficients.

\section{Literature Cited}

Association of Official Agricultural Chemists. 1965. Official methods of analysis. Ass. Off. Agr. Chem., Washington, D.C. 10th Ed. 975 p

Cook, C.W., and L.E. Harris. 1950. The nutritive value of range forage as affected by vegetation type, site and state of maturity. Utah State Agr. Exp. Sta. Tech. Bull. No. 344. 45 p.

Costello, D.F. 1954. Vegetation zones in Colorado. p. iii-x In: H.D. Harrington. Manual of the Plants of Colorado. Sage Books. Denver. Colo. $666 \mathrm{p}$.

Dixon, W.J., and F.J. Massey, Jr. 1969. Introduction to Statistical Analysis. McGraw-Hill, N.Y. 3rd Ed. 638 p.

Fonnesbeck, P.V., and L.E. Harris. 1970a. Determination of plant cell walls in feeds. Proc. Western Sec. Amer. Soc. Anim. Sci. 21:153-161.

Fonnesbeck, P.V., and L.E. Harris. 1970b. Determination of holocellulose. lignin and silica of plant cell walls. Proc. Western Sec. Amer. Soc. Anim. Sci. 21:162-164.

Fonnesbeck, P.V., and L.E. Harris. 1971. Determining hemicellulose in plant cell walls. Proc. Western Sec. Amer. Soc. Anim. Sci. 22:77-82.

Laycock, W.A., and D.A. Price. 1970. Factors influencing forage quality. p. 37-47 In: Range and wildlife habitat evaluation-a research symposium. USDA For. Serv. Misc. Pub. No. 1147. 220 p

Nagy, J.G., H.W. Steinhoff, and G.M. Ward. 1964. Effects of essential oils of sagebrush on deer rumen microbial function. J. Wildl. Manage. 28:785-790.

Pearson, H.A. 1970. Digestibility trials: In vitro techniques. p. 85-92 In: Range and wildlife habitat evaluation-a research symposium. U.S. Dep. Agr. Forest Serv. Misc. Publ. No. 1147. 220 p.

Tilley, J.M.A., and R.A. Terry. 1963. A two-stage technique for the in vitro digestion of forage crops. J. Br. Grassl. Soc. 18:104-111.

Ward, G.M., and J.G. Nagy. 1966. Bacterial inhibition by the essential oils of sagebrush. Final Rep. to Natl. Sci. Found. Grant No. GB 1507. Colorado State Univ., Fort Collins. 54 p. 